\title{
特集：B 細胞と自己免疫
}

総

説

\section{多発性硬化症病態におけるプラズマブラスト}

\author{
中村雅 一11, 荒木 学*2, 山村 隆*1,2
}

\section{Plasmablast in the pathology of multiple sclerosis}

\author{
Masakazu NAKAmUrA $^{* 1}$, Manabu ArAKI ${ }^{* 2}$ and Takashi YamamurA ${ }^{* 1}$ \\ ${ }^{* 1}$ Department of Immunology, National Institute of Neuroscience, National Center of Neurology and Psychiatry (NCNP), Tokyo, Japan \\ ${ }^{* 2}$ Multiple Sclerosis Center, NCNP
}

(Accepted August 5, 2015)

summary

\begin{abstract}
Multiple sclerosis (MS) is an autoimmune disease targeting oligodendrocyte in the central nervous system and involves heterogeneous pathology that yields considerable nonresponders to the first line therapy interferon (IFN)- $\beta$. However, determinants for this clinical efficacy have not been elucidated. Interestingly, an MS-like autoimmune disease neuromyelitis optica (NMO) is exclusively resistant to this therapy and mediated by IL-6-dependnet PBs via producing a disease-specific autoantibody against aquaporin 4 (AQP4) on astrocyte. Therefore, we assumed that IFN- $\beta$-nonresponsive patients with MS may have the similar B-cell abnormality and found an expansion of circulating PBs in these nonresponders. In addition, these PBs exhibited an IL-6-dependent survival in vitro like those in NMO. Clinical features of such "PB-high" patients were consistent with antoantibody-mediated pathology. Thus, we are administering anti-IL-6 receptor blocking antibody tocilizumab to these intractable patients with MS to achieve precision medicine for MS.
\end{abstract}

Key words_— multiple sclerosis; interferon- $\beta$; plasmablast; IL-6; precision medicine

\section{抄 録}

多発性硬化症（MS）は，中枢神経系のオリゴデンドロサイトを標的とする自己免疫疾患と考えられているが， 病態の多様性に基づき第 1 選択薬 interferon（IFN)- $\beta$ に対する相当数のノンレスポンダーが存在する。一方，標的 抗原がアストロサイトのアクアポリン 4 (AQP4) であることが判明し, MS より分離された視神経脊髄炎 $(\mathrm{NMO})$ は，IFN- $\beta$ 投与により顕著に悪化する。NMOでは，末梢由来プラズマブラスト（PB）が中枢神経系に浸潤し， IL-6 依存性に抗 AQP4 抗体を産生して炎症を惹起することが示されている。そこで，MSにおけるIFN- $\beta$ ノンレス ポンダーも抗原特異性は異なるが，同様の病態構造を有する可能性を疑った。実際に，MSでは，末梢血 PB 増加 (PB-high) 群にIFN- $\beta$ ノンレスポンダーが集積しており, これらのPB は in vitroにおいて IL-6 依存性を示した. 臨床所見からは，自己抗体の介在による進行性亜群であることが示唆された。私達は, MS におけるプレシジョン 医療を目指して，PB-high 群に抗 IL-6 受容体抗体 tozcilizumab の投与を試みている。

\section{多発性硬化症病態の多様性}

多発性硬化症（multiple sclerosis: MS）は，中枢神 経系に扮けるミエリン構成成分を標的とする自己免 疫疾患と考えられている.MS 動物モデルである実 験的自己免疫性脳脊髄炎 (experimental autoimmune encephalomyelitis: EAE) が，ミエリン特異的 CD4 陽性 $\mathrm{T}$ 細胞の移入により再現されることが主要な

\footnotetext{
${ }^{* 1}$ 国立精神・神経医療研究センター 神経研究所免疫研究部

*2 国立精神・神経医療研究センター多発性硬化センター
}

根拠とされる ${ }^{1)}$. 中枢神経系では，グリア細胞であ るオリゴデンドロサイト (oligodendrocyte) が髄鞘 を形成して神経軸索の機能的，あるいは代謝的補助 に働くが，この髄鞘はミエリンを豊富に含むため， MS は一次的なオリゴデンドロサイト障害（oligodendropathy）と考えられている2)。このように疾患概念 は明瞭であるが, 臨床的には病態の多様性が問題に なる，診断基準では，脳，春䯋，及び視神経におけ る局所炎症に伴う神経症状を反復する状態と定義さ れ，神経症状の再発とそれを説明し得るMRI 病変 が確認できれば診断可能である。しかし，特異性 
の高い検査所見がそしいため, 中枢神経系に多発 病変を形成する疾患群の混在を許容する ${ }^{3)}$. 一方, この再発性の臨床経過は「再発寛解型（relapsingremitting: RR)」と記述されるが, 再発毎の後遺症 の蓄積は深刻である。また，病状の進行とともに 再発と関係なく障害度が悪化していく「二次進行 型（secondary progressive: SP）」病態に移行するた め, 早期治療介入の重要性が唱えられている ${ }^{4)}$. そ こで，再発を待たずに初回発作（clinically-isolated syndrome: CIS）の段階で診断できるように国際診断 基準も改訂されたが, 発症早期の他疾患との鑑別は より難しい3）。このようにして形成される病態の多 様性は標準治療におけるノンレスポンダーを生み出 す原因となるため, 早期診断が常に予後改善に有益 であるとは限らない，従って，MS 診断基準を満た す病態群の解明と, それに応じた治療法の選択が必 要である。実際に，MS脳病変病理では，少なくと も 4 つの型が指摘されており ${ }^{5)}, \operatorname{IgG}$ と補体の沈着 より自己抗体の関与が想定される Type2 病変を有す る症例に限り，再発時の血漿交換療法が有効である ことも報告されている゙

\section{多発性硬化症における interferon- $\beta$ 治療の問題点}

再発寛解型 MS（RR-MS）の再発予防治療とし て, interferon (IFN)- $\beta$ が第 1 選択薬として使用され てきた，作用機序に不明な点があるが，無作為化比 較試験（randomized controlled trial: RCT）では有効 性が確認されている。免疫抑制治療とは異なり, 感 染症, 及び悪性腫瘍の合併を促進しないことも, 直 接的な死因になりにくいMS の治療には重要な利点 である7)。 RCT では IFN- $\beta$ は RR-MS の再発を $30 \%$ 減少させることが示されてきたが，「30\%しか減少 させない」との解釈も可能であり, その裏返しとし て 20-50\%もの患者がノンレスポンダーであること は深刻である ${ }^{8)}$ 。そこで, IFN- $\beta$ レスポンダーとノ ンレスポンダーとの病態の相違が議論されてきた。 最も信頼されている同薬抵抗性因子は, 抗 IFN- $\beta$ 中和抗体の産生である. 統一的な血清抗体価測定 法も確立され, 高力価群は抵抗性を示すこともわ かっている.しかし, この中和抗体ではノンレスポ ンダーの $15 \%$ 程度しか説明できないため, 他の原 因の特定が必要である ${ }^{9)}$ 。その候補として，末梢血 単核細胞 (peripheral blood mononuclear cell: PBMC) における Type I IFN signature 強度 ${ }^{10-12)}$, 単球におけ る TNF-related apoptosis-inducing ligand (TRAIL) 誘
導能 $^{13,14)}$ などが報告されてきたが，抗 IFN- $\beta$ 中和抗 体ほどのコンセンサスは得られていない. 最近では, IFN- $\beta$ 投与により Th1 誘導性 EAE は改善するが, Th17 誘導性 EAE は IL-17F 産生を介して悪化するこ とが示され，ヒト病態との関連が注目された ${ }^{15)}$ 。し かし, MS における血清 IL-17F 濃度は同薬抵抗性と 相関しなかったことから，この仮説は否定的に捉え られている ${ }^{16,17)}$ 。この結果は, 動物とヒトでの病態 の解離との解釈もできる。しかし, 先の RCT と同 様に，Th17 偏諱による IFN- $\beta$ 抵抗性を示す一部の ノンレスポンダーが統計処理の影に埋もれている危 険性もある。いずれにしても，MSにおけるIFN- $\beta$ 抵抗性病態には不明な点が多く, IFN- $\beta$ ノンレスポ ンダーを予測する, さらに，ノンレスポンダーの病 態に応じた治療を選択することは容易ではない。

\section{自己反応性プラズマブラストと interferon- $\beta$ 抵抗性}

治療として Type I IFNs を投与される自己免疫疾 患は稀である。全身性エリテマトーデス（systemic lupus erythematosus: SLE) では, 内因性 Type I IFNs は，自己反応性プラズマブラスト（plasmablast: PB） の分化促進により自己抗体介在性炎症を悪化させ ることが知られている ${ }^{18)}$. 自己反応性 PB が病態形 成に関与する neuromyelitis optica (NMO) \& IFN- $\beta$ 投与により増悪するが ${ }^{19)}$, この疾患の発見, 及び病 態解明はMS 研究と深く関係する. 日本人 MSに は, 脳病変が少なく, 脊髄と視神経に病変が集中す る症例が多く，視神経脊髄型 MS（optic-spinal MS: OS-MS）と呼ばれていた。 OS-MS は，一度の再発 により失明したり，車椅子レベルの歩行障害を来 すなど重症度が高く，IFN- $\beta$ 投与中に激烈な再発が 惹起される症例が知られており, 脳病変の豊富な 古典的 MS (conventional MS: cMS) との異動が議論 されてきだ20).しかし，2005年にLennon らにより OS-MS 患者血清における特異的自己抗体の存在が 指摘され ${ }^{21)}$ ，血液脳関門（blood-brain barrier: BBB） を構成する中枢神経系のグリア細胞であるアストロ サイト (astrocyte) の足突起に分布するアクアポリ ン 4 (aquaporin 4: AQP4) 水チャネルを標的とする ことが明らかにされた ${ }^{22)}$. そして，この抗 $\mathrm{AQP4}$ 抗 体によるアストロサイト障害（astrocytopathy）を病 理変化の主体とする疾患は, $\mathrm{NMO}$ として MS から 分離された ${ }^{23)}$. Chihara らは, NMO 患者末梢血 PB による抗 AQP4 抗体産生を in vitro で確認するとと もに, その生存, 及び抗体産生能が IL-6 シグナル 
により克進し, 患者血清含有培地では, 抗 IL-6 受 容体抗体により抑制されることを見出した ${ }^{24)}$. MS に比してNMO では血清, 及び髄液での IL-6 濃度 が高く ${ }^{25)}$ ，豊富な IL-6 産生を背景に IL-6 依存性 PB による自己抗体産生が病態形成に寄与すると推測 された。Araki らは，抗 IL-6 受容体抗体 tocilizumab （TCZ）が NMO の再発を劇的に抑制することを報 告し, NMO 病態における IL-6 依存性 PB の重要 性を示した ${ }^{26)}$ 。また, Chiharaらは, 患者血中, 及 び髄液中の単一 $\mathrm{PB}$ を分離し, $\operatorname{IgG}$ 重鎖における相 補性決定領域 (complementarity determining eregion: CDR）をシークエンスし, 同一クローンを高率に検 出した ${ }^{27)}$ 。つまり, NMO 中枢神経で炎症に関与す るPB は末梢由来であることが示唆された. IFN- $\beta$ 投与によるNMO 悪化には, SLE と同様に Type I IFNs による PB 介在性病態の促進が関与する可能性 が強く疑われる。NM と SLEの合併がしばしば観 察されることからも両疾患の免疫学的背景の類似性 が伺える ${ }^{23)}$. 一方, 自己反応性 PB に扮ける IL-6 依 存性は, $\mathrm{NMO}$ 病態を特徵付ける所見である可能性 がある。

\section{interferon- $\beta$ ノンレスポンダー prototype としての 視神経脊髄炎}

抗 AQP4 抗体の発見により NMO における IFN- $\beta$ 投与を回避できるようになった MS 治療において画期的なことであったが, 血清抗 AQP4 抗体陰性であっても IFN- $\beta$ 抵抗性を示す患者 は相当数存在する。 そこで, 著者らは, 末梢由来 $\mathrm{PB}$ による自己抗体産生が病態形成に重要な $\mathrm{NMO}$ 様病態構造を有する RR-MS 亜群が, 同薬抵抗性を 示す可能性を疑った. MS と自己抗体, 及び抗体産 生細胞である PB, あるいは, その最終分化型であ る plasma cell (PC) との関連を示す所見は複数報 告されている。先述の通り, 一部の患者の脳病変

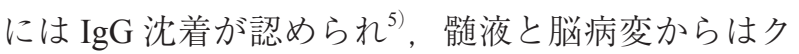
ローン増殖を示す Ig 重鎖配列が検出されることか $ら^{28-31)}$, 自己反応性 PB, あるいは, PC が中枢神経 系内で抗体産生を介して病巣形成に寄与することが 示唆される。 また, 患者血中, 及び髄液中に同一ク ローンのB 細胞が確認され ${ }^{32)}$, さらに, 一部の患者 血清中には, in vitro で oligodendropathy を惹起し得 る抗ミエリン抗体が認められることから ${ }^{33)}$ ，中枢神 経内における自己反応性 PB，あるいはPCの少な くとも一部は, 末梢由来と推測される. 二次進行型
MS（SP-MS）では，髄膜にリンパ節様構造が形成 され 孔 $^{34,35)}$ ，中枢神経内での自己反応性リンパ球の供 給も想定されるが，その前段階の RR-MS では，末 梢からの浸潤がより重要である可能性が疑われる.

\section{多発性硬化症における末梢血 PB の増加}

上記の仮説を示すべく, RR-MS 患者血中 PB をフ ローサイトメトリーで解析した（図 $1 \mathbf{A}$ ) . PB の定義 は, Chihara らの NMO 研究に基づき, $\mathrm{CD} 19^{+} \mathrm{CD} 27^{+}$ $\mathrm{CD} 180^{-} \mathrm{CD} 38^{\text {high }}$ とした。 SLE 患者由来 B 細胞では CD180 陰性分画に抗 double-stranded DNA 抗体産生 細胞が集積することから，CD180 は自己抗体産生 性 B 細胞の特定に有用と考えられた ${ }^{36)}$.この $\mathrm{PB} の$ $\mathrm{CD} 19$ 陽性 B 細胞に占める割合 (PB 頻度 [\%])

A
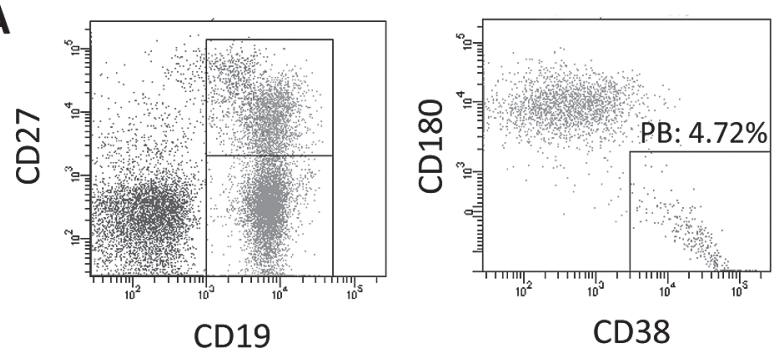

B

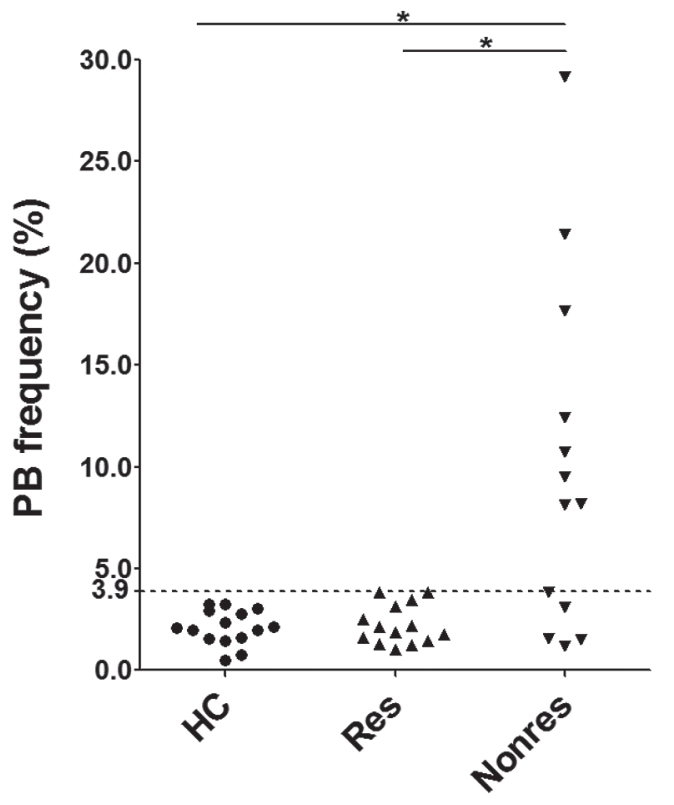

図 1 RR-MS 亜群における末梢血 PB 頻度の相違

(A) フローサイトメトリーによる末梢血 PB のゲーティン グを示した. $\mathrm{PBMC}$ 中の $\mathrm{CD}^{-} \mathrm{CD} 14^{-}$細胞を CD19 と CD27 で展開し， $\mathrm{CD} 19^{+} \mathrm{CD} 27^{+}$分画を特定する(左).さらに, こ の分画を CD180 と CD38 で展開し, CD $180^{-} \mathrm{CD} 38^{\text {high }}$ 分画を $\mathrm{PB}$ とした（右）。プロット内の数字は, CD19 陽性 B 細胞に 占める PB の割合（PB 頻度：\%）を示す。

(B) RR-MS 患者を IFN- $\beta$ レスポンダー (Res; $n=14)$ とノ ンレスポンダー (Nonres; $n=13)$ とに分類し，健常者 $(\mathrm{HC}$; $\mathrm{n}=14$ ）と末梢血 PB 頻度を比較した。点線は，HCに扮け る $\mathrm{PB}$ 頻度の平均 $+2 \mathrm{SD}$ を示す。

$* p<0.01$ by Kruskal-Wallis test with post hoc Dunn's test. 
は，健常人と IFN- $\beta$ レスポンダーでは同等であっ たが，IFN- $\beta$ ノンレスポンダーでは有意に高かった (図 1 B). SLE，及びNMOにおける末梢血PBの増 加は, $\mathrm{PB}$ 介在性病態の活動性を反映するため ${ }^{24,37)}$, RR-MS におけるこの結果は，著者らの仮説を支持 する。 ここで，健常人における平均 $+2 \mathrm{SD}$ をカット オフ值として RR-MS 患者をPB-low，あるいは PBhigh 群とに分類すると（図 1 B), IFN- $\beta$ 治療反応性 の他にも幾つかの臨床的相違点が明らかとなった。

PB-high 群は，1）抗核抗体や抗甲状腺抗体など血 清自己抗体保有率が高く（データは省略），2）MRI における脳病変の分布が広く（図 $2 \mathbf{A}$ )，3）Expanded Disability Status Scale (EDSS) ${ }^{38)}$ で評価した臨床的 障害度が罹病期間と相関した（図 2 B）。1）に示さ れる自己抗体産生性の獲得は, B 細胞分化におけ る免疫寛容の破綻を前提とする。 Kinnunen らは, 中枢性, あるいは末梢性免疫寛容機構を通過した 末梢血 transitional，あるいはナイーブ B 細胞による 自己抗体産生を指標に, MS では Foxp3 陽性制御性 $\mathrm{T}$ （Treg）細胞の機能低下による末梢性機構の破綻
が顕著であることを示した ${ }^{39)}$ 。一方，肧中心におけ る $\mathrm{PB}$ 分化は, 濾胞性ヘルパー $\mathrm{T}$ ( Tfh) 細胞により 促進され, Treg 由来の濾胞性制御性 T (Tfr) 細胞 により抑制される。末梢血では，ともに CXCR5 陽 性メモリーCD4 陽性 T 細胞分画に含まれる ${ }^{40,41)}$. そこで, RR-MS 由来同 $\mathrm{T}$ 細胞分画の遺伝子発現解 析を行ったところ, PB-high 群におけるFoxp3 発現 の低下を見出した（未発表データ）。この所見は, 同群における高度の末梢性免疫寛容の破綻に矛盾 せず，さらに，自己反応性 PB 分化を促進する要因 と推測される。2)は，自己抗体による組織障害範 囲の拡大と解釈し得る. 自己抗体介在性病態を有 する NMO でも脳病変の合併が報告されているが, MS と比較して粗大な性状を特徴とする ${ }^{42)}$. 3) は, この広範な脳病変に対応する臨床所見と考えられ る。一方, 罹病期間に相関する障害度の進行は, むしろ SP-MS の特徵と考えられるが43)， SP-MS 患 者の末梢血 $\mathrm{PB}$ 頻度も健常人に比して高い傾向があ ることから (未発表データ), 自己反応性 PB の慢 性進行性病態における関与が疑われる。 RR-MS と
A

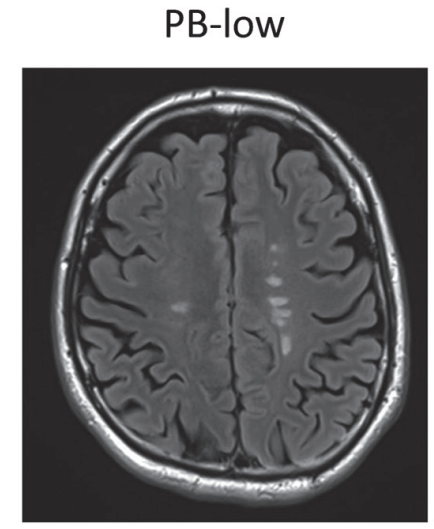

B

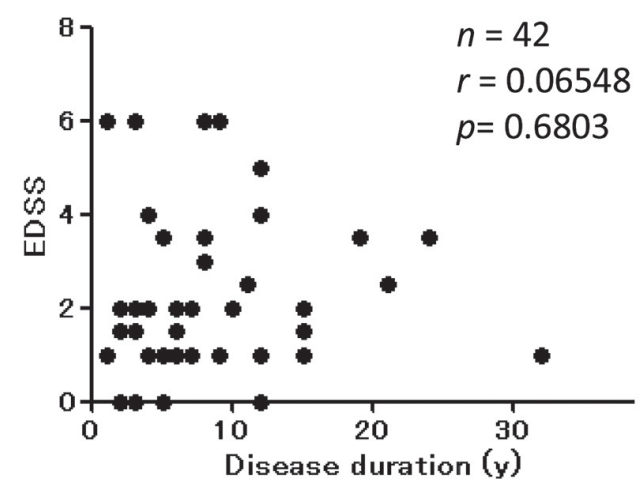

PB-high

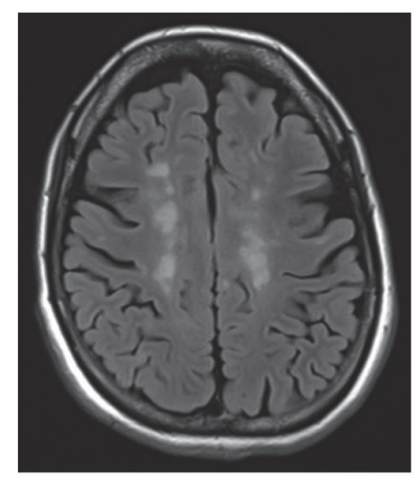

PB-high

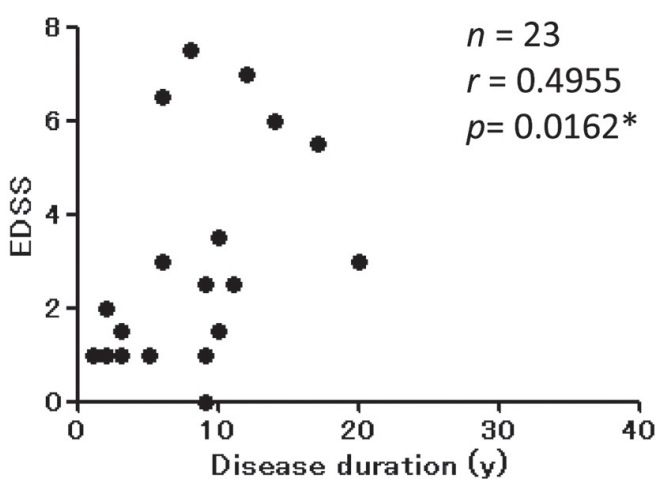

図 2 RR-MS 亜群の臨床的特徵

(A) PB-low（左），及び PB-high（右）患者における脑 MRI（FLAIR 画像）の水平断を示す. PB-high 患者では，MSに典型的な 側脳室周囲の ovoid lesion が広範である。

(B) PB-low $(n=42)$, 及び PB-high $(n=23)$ 患者に扔ける臨床的障害度の指標である EDSS と罹病期間（年）との相関を示した. r: Spearman の相関係数. ${ }^{*} p<0.05$. 
の区別が難しいが，進行性病態の混在を示唆する progressive-relapsing (PR) との臨床経過も指摘され ており ${ }^{43)}$ ，PB-high RR-MSの多くが“PR-MS” に該 当する可能性がある.

\section{多発性硬化症病態における}

IL-6 依存性プラズマブラスト

平成 27 年 7 月現在, 日本で保険適用のある RRMS 再発予防薬には, IFN- $\beta$ の他, natalizumab と finglolimod がある。 natalizumabは, リンパ球上の a4-integrinに対するモノクローナル抗体であり， 末梢由来自己反応性リンパ球の $\mathrm{BBB}$ 通過を抑制 する44). fingolimod は, リンパ球上の sphigosine-1phosphate receptor 1（S1P1）に対する機能的アンタ ゴニストであり，自己反応性リンパ球の二次リンパ

A

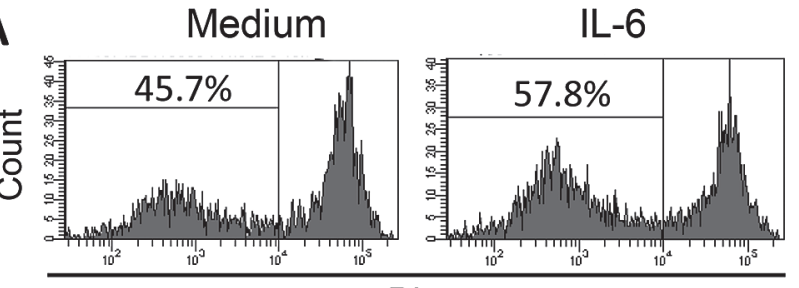

$\mathrm{Pl}$

B

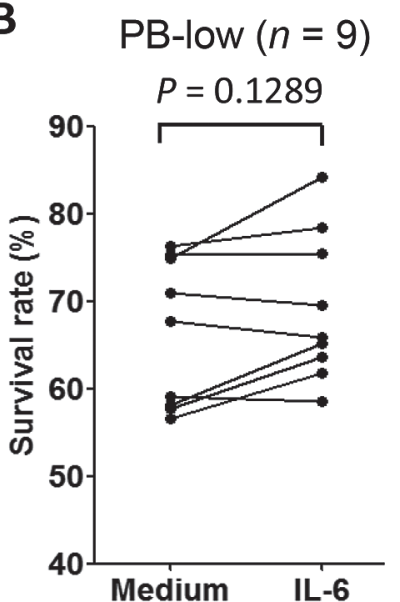

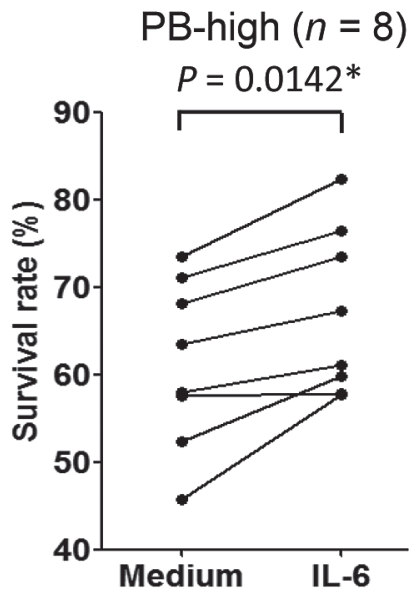

組織からの移出を抑制する ${ }^{45)}$. 現状では，第 1 選択 薬である IFN- $\beta$ が無効の場合，いずれかの薬剤を選 択することになる。しかし, natalizumabの治療効 果は髄液 PB の減少と関連することが報告されてお $り^{46)}$, fingolimod は NMO に腫瘍様病変による増悪 を来し ${ }^{47)}$ ，成熟した CD138 陽性 PB に対して効果が 弱い可能性があり ${ }^{48)}$ ，これらの薬剂が PB 介在性病 態治療に有効である保証はない。そこで，著者らは， IFN- $\beta$ ノンレスポンダーにおける病態に則した治療 法の確立が必要と考え，NMOに倣って IL-6 依存性 PB が治療標的になり得ないか検討を行った。PBlow，及び PB-high RR-MS 末梢血 PB を分離し， IL-6 存在下で培養すると, PB-high 群では生存率の改善 を認めた（図 3 A, B )。一方，PBMC を抗 IL-6 受容 体抗体で処理した後に患者血清含有培地で培養する
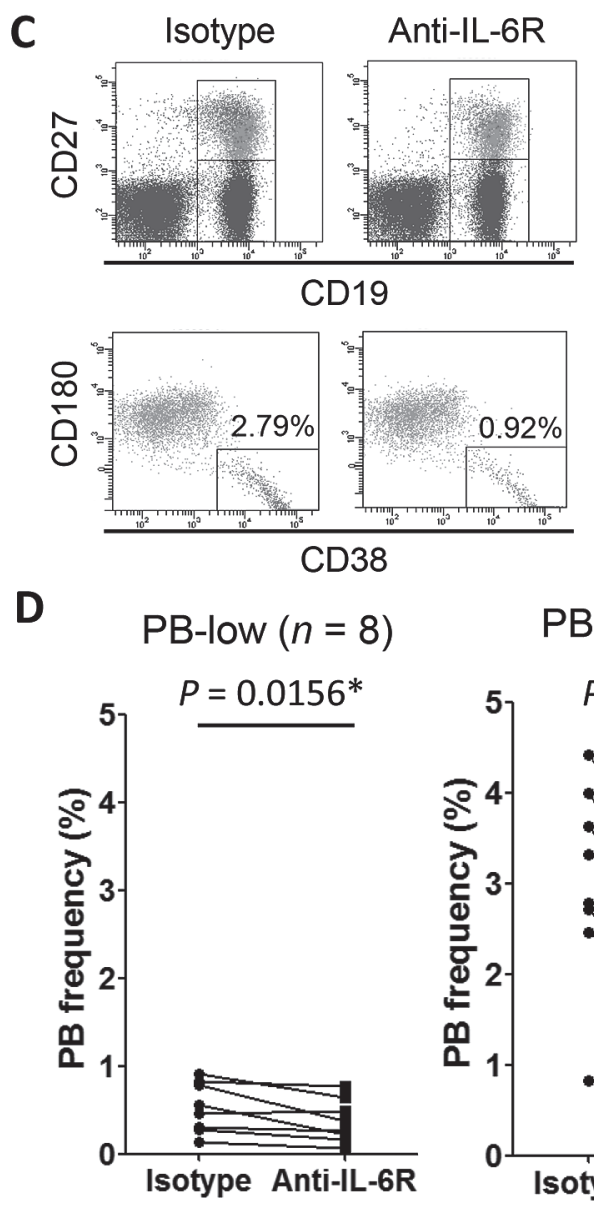

PB-high $(n=8)$

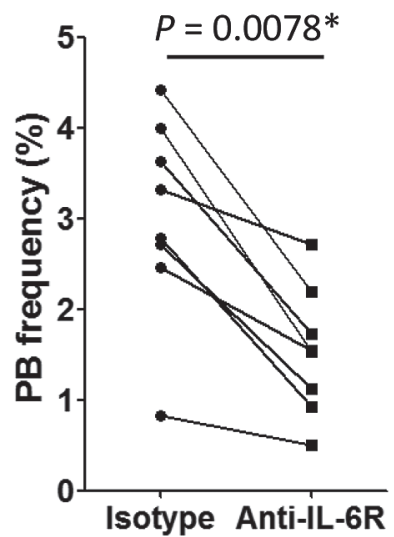

図 3 PB-high RR-MS の末梢血 PB における IL-6 依存性

(A, B) RR-MS 患者末梢血 PB を IL-6 存在下 (IL-6), 非存在下 (Medium) で 2 日間培養し, propidium iodide (PI) 染色を行い フローサイトメトリーにより生存率を測定した。

(A) PI に関するヒストグラムを示す.PI- 分画が生存細胞である。数字（\%）は生存率を表す

(B) PB-low $(n=9)$ ，または PB-high $(n=8)$ 患者における IL-6 存在下（IL-6）, 非存在下 (medium) での PB 生存率を比較し た. $* p<0.05$ by paired t-test.

（C, D） RR-MS 患者PBMC を抗 IL-6 受容体抗体（Anti-IL-6R），またはアイソタイプコントロール抗体（Isotype）にて前処理し， 各々の血清含有培地にて 2 日間培養し, PB 頻度を測定した

(C) 典型的には，抗 IL-6 受容体抗体添加により PB 頻度が減少した。プロット内の数字は，PB 頻度（\%）を示す。

(D) PB-low $(n=8)$ ，または PB-high $(n=8)$ 患者における両条件下での PB 頻度を比較した。* $p<0.05$ by paired t-test. 
と, PB-high 群において著しいPB 頻度の減少を認 めた（図 $3 \mathbf{C}, \mathbf{D}$ )。つまり, PB-high RR-MS 由来 PB は, in vitro において IL-6 依存性を示すことがわかっ た。血清 IL-6 濃度は PB-low，及び PB-high RR-MS に拉いて差がないが（デー夕は省略），PBにおける membrane-bound IL-6 receptor (IL-6R) と glycoprotein 130（gp130）の発現は, PB-high 群において有 意に高かった（図 4 A,B）。従って, PB-high RR-MS 由来 PB に打ける顕著な IL-6 依存性は, PB の IL-6 に対する高い感受性に起因すると推測され, 血清 IL-6 上昇を特徵とする NMO とは PB 介在性病態の 成因が異なることが示唆される ${ }^{25)}$. IFN- $\beta$ 抵抗性と の関連では, 外因性 IFN- $\beta$ は全身性 IL-6 を誘導す る点が重要である ${ }^{49)}$ ，著者らの研究部でも DNA マ イクロアレイを用いて IFN- $\beta$ で刺激したヒト PBMC ではIL-6mRNA が急激に誘導されることを確認し $た^{50)}$ 。従って, 外因性 IFN- $\beta$ により誘導された IL-6 は, PB-high RR-MS に扔ける高感受性 PB の生存を 選択的に促進し, 自己抗体産生を光進させる構図が 想定される。そのため, RR-MSに扮けるIFN- $\beta$ 抵 抗性とは, IL-6 を介したPB 介在性病態の悪化と推 測される（図 5 )。“IFN- $\beta$ ノンレスポンダー”と言

\section{Responder}

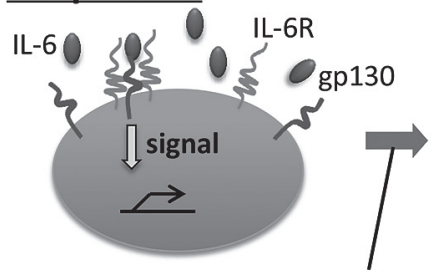

Nonresponder Survival

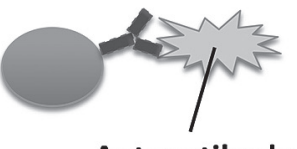
Autoantibody -mediated pathology

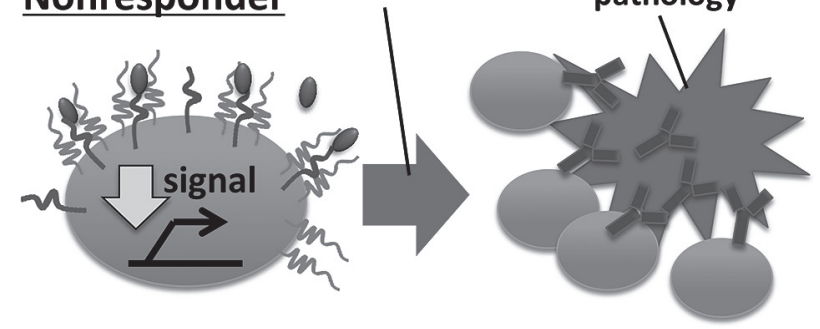

図 5 RR-MS における IFN- $\beta$ 抵抗性の発現機序についての 仮説

IFN- $\beta$ 投与に伴い誘導される IL-6 により IL-6R，及び gp130 を高発現する PB が選択的に増加する。その結果, 特定の RR-MS 亜群において自己抗体介在性病態が悪化し, 同薬抵 抗性として観察されると推測される.

われるが, 再発回数が減少しないというより病状 が悪化する例を多数経験する。 また，IFN- $\beta$ 投与中 RR-MS 患者の末梢血. PB 遺伝子発現解析では, PBhigh 群において CDKN1A（p21）の発現克進を認め

A
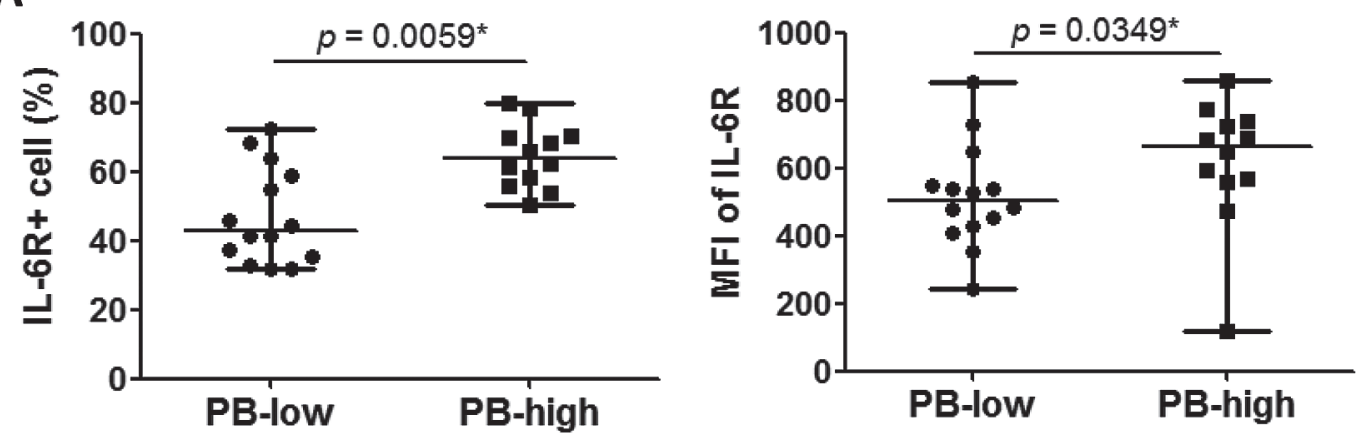

B
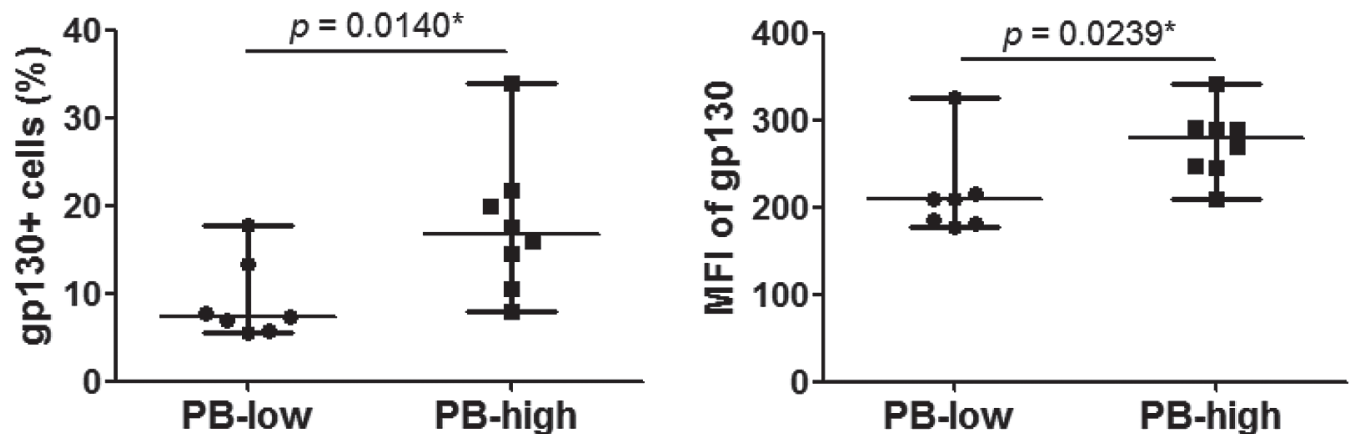

図 4 RR-MS 末梢血 PB における IL-6R, 及び gp130 の発現

RR-MS 患者末梢血 PB の IL-6R，及び gp130の発現量をフローサイトメトリーを用いて測定した。

(A) PB における IL-6R 陽性細胞頻度, 及び IL-6R 発現の平均蛍光強度 $(\mathrm{MFI})$ を PB-low $(n=14)$, PB-high $(n=12)$ 患者間で 比較した。

(B) PB における gp130 陽性細胞頻度, 及び gp130 発現の MFI を PB-low $(n=7)$, PB-high $(n=8)$ 患者間で比較した。プロット 内の水平線は, 中間值, 及び範囲を表す。 $* p<0.05$ by Mann-Whitney U-test. 
表 1 PB-high 患者由来 PB における高発現遺伝子

\begin{tabular}{ccccc}
\hline \hline $\begin{array}{c}\text { Gene } \\
\text { symbol }\end{array}$ & $\begin{array}{c}\text { PB-high } \\
\text { (Normalized) }\end{array}$ & $\begin{array}{c}\text { PB-low } \\
\text { (Normalized) }\end{array}$ & $\begin{array}{c}\text { Fold change } \\
\text { PB-high/-low }\end{array}$ & p \\
\hline CDKN1A & 252.55 & 118.22 & 2.136 & 0.038 \\
TNFAIP3 & 399.12 & 290.68 & 1.373 & 0.032 \\
NFKBIA & 972.84 & 736.86 & 1.320 & 0.010 \\
\hline
\end{tabular}

IFN- $\beta$ 投与中 PB-low IFN- $\beta$ responder $(n=3)$ と PB-high IFN- $\beta$ nonresponder $(n=3)$ に打ける末梢血 PB の遺伝子発現を nCounter （Nanostring Technologies 社）を用いて比較し，PB-high 群で有意に 高い遺伝子を記載した。P 值は，各遺伝子の標準化した発現量を 基に，Welch の $\mathrm{t}$ 検定にて算出した。

る（表 1 ）。p21 は，IL-6 シグナルにより誘導され ${ }^{51)}$, PB の機能的分化を抑制する ${ }^{52)}$. 従って，この所見 は, PB-high 群における高感受性 PB が in vivo で強 いIL-6 シグナルを受けており, 過度の PB 分化の代 償としても作用していると推測される。このよう に，著者らは，IL-6がRR-MSに扔けるIFN- $\beta$ 抵抗 性において重要な役割を果たすことを示したが, IL-6 に対する PB の高感受性は, IFN- $\beta$ 非投与時に も RR-MS 亜群の病態の差違を形成し得ると考えて いる.

\section{多発性硬化症亜群（PB-high RR-MS）における 抗 IL-6 受容体抗体治療}

著者らは, この難治性 RR-MS 西群に TCZ 投与 を試みる臨床研究を展開中であり（再発寛解型多発 性硬化症に扮ける抗インターロイキン 6 受容体抗 体治療の有効性と安全性に関する研究：UMIN0000 12705), 治療有効例を確認している. in vitro デー 夕との解離も認められるが，それにより RR-MSに おける IL-6 の PB 分化に果たす役割について本質的 な議論が可能となる，EAEでは，PB，あるいは PC による制御性サイトカイン産生の重要性も注目され ており ${ }^{53,54)}$ ，この点についても検討中である. 最近 のヒト検体を用いた研究では，IL-6 は MSに扔ける 自己反応性 CD4 陽性 T 細胞を Treg 細胞による制御 から回避させることで炎症惹起に働くことが注目さ れてきた ${ }^{55,56)}$ 。また，数年前に rituximabによる $\mathrm{B}$ 細胞除去治療が MS 再発を減少させるが，CD20の 発現を欠く $\mathrm{PB}$ ，あるいは $\mathrm{PC}$ は直接除去されない ため, 抗体産生細胞を標的とせずとも MS 病態は 抑制し得るとの考えもある ${ }^{57)}$ 。そのような背景から は，著者らの視点に否定的な意見もあると思われる が, これまでの臨床研究, あるいは治験と決定的に 異なっているのは，著者らは， RR-MS 全体ではな く，RR-MSに拈特定の亜群を治療標的として いる点にある，前述の通り， RR-MS 全体で統計上
有意な治療効果が得られたとしても，必ず相当数の 治療抵抗性例が存在する。従って, RCT デー夕は, 目の前の患者が有効例なのか否か, 判断する基準を 与えてくれない.このような unmet medical needs に 応えること, 即ち, MS 治療に扔けるプレシジョン 医療（precision medicine）の実現に著者らの仕事の 意味があると考える。

\section{文献}

1) Comabella, M., Khoury, S.J.: Immunopathogenesis of multiple sclerosis. Clin Immunol. 142: 2-8, 2012.

2) Compston, A., Coles, A.: Multiple sclerosis. Lancet. 372: 1502-1517, 2008.

3) Polman, C.H., et al.: Diagnostic criteria for multiple sclerosis: 2010 revisions to the McDonald criteria. Ann Neurol. 69: 292-302, 2011.

4) Duddy, M., et al.: Managing MS in a changing treatment landscape. J Neurol. 258: 728-739, 2011.

5) Lucchinetti, C., et al.: Heterogeneity of multiple sclerosis lesions: implications for the pathogenesis of demyelination. Ann Neurol. 47: 707-717, 2000.

6) Keegan, M., et al.: Relation between humoral pathological changes in multiple sclerosis and response to therapeutic plasma exchange. Lancet. 366: 579-582, 2005.

7) Killestein, J., Polman, C.H.: Determinants of interferon beta efficacy in patients with multiple sclerosis. Nat Rev Neurol. 7: 221-228, 2011.

8) Sormani, M.P., De Stefano, N.: Defining and scoring response to IFN-beta in multiple sclerosis. Nat Rev Neurol. 9: 504-512, 2013.

9) Sbardella, E., et al.: Neutralizing antibodies explain the poor clinical response to interferon beta in a small proportion of patients with multiple sclerosis: a retrospective study. BMC Neurol. 9: 54, 2009.

10) Comabella, M., et al.: A type I interferon signature in monocytes is associated with poor response to interferon-beta in multiple sclerosis. Brain. 132: 3353-3365, 2009.

11) van Baarsen, L.G., et al.: Pharmacogenomics of interferon-beta therapy in multiple sclerosis: baseline IFN signature determines pharmacological differences between patients. PLoS One. 3: e1927, 2008.

12) Rudick, R.A., et al.: Excessive biologic response to IFNbeta is associated with poor treatment response in patients with multiple sclerosis. PLoS One. 6: 
e19262, 2011.

13) Wandinger, K.P., et al.: TNF-related apoptosis inducing ligand (TRAIL) as a potential response marker for interferon-beta treatment in multiple sclerosis. Lancet. 361: 2036-2043, 2003.

14) Zula, J.A., et al.: The role of cell type-specific responses in IFN-beta therapy of multiple sclerosis. Proc Natl Acad Sci U S A. 108: 19689-19694, 2011.

15) Axtell, R.C., et al.: T helper type 1 and 17 cells determine efficacy of interferon-beta in multiple sclerosis and experimental encephalomyelitis. Nat Med. 16: 406-412, 2010.

16) Bushnell, S.E., et al.: Serum IL-17F does not predict poor response to IM IFNbeta-1a in relapsingremitting MS. Neurology. 79: 531-537, 2012.

17) Hartung, H.P., et al.: Interleukin $17 \mathrm{~F}$ level and interferon beta response in patients with multiple sclerosis. JAMA Neurol. 70: 1017-1021, 2013.

18) Hiepe, F. et al.: Long-lived autoreactive plasma cells drive persistent autoimmune inflammation. Nat Rev Rheumatol. 7: 170-178, 2011.

19) Shimizu, J., et al.: IFNbeta-1b may severely exacerbate Japanese optic-spinal MS in neuromyelitis optica spectrum. Neurology. 75: 1423-1427, 2010.

20) Kira, J., et al.: Western versus Asian types of multiple sclerosis: immunogenetically and clinically distinct disorders. Ann Neurol. 40: 569-574, 1996.

21) Lennon, V.A., et al.: A serum autoantibody marker of neuromyelitis optica: distinction from multiple sclerosis. Lancet. 364: 2106-2112, 2004.

22) Lennon, V.A., et al.: IgG marker of optic-spinal multiple sclerosis binds to the aquaporin-4 water channel. J Exp Med. 202: 473-477, 2005.

23) Wingerchuk, D.M., et al.: The spectrum of neuromyelitis optica. Lancet Neurol. 6: 805-815, 2007.

24) Chihara, N., et al.: Interleukin 6 signaling promotes anti-aquaporin 4 autoantibody production from plasmablasts in neuromyelitis optica. Proc Natl Acad Sci U S A. 108: 3701-3706, 2011.

25) Uzawa, A., et al.: Cytokine and chemokine profiles in neuromyelitis optica: significance of interleukin-6. Mult Scler. 16: 1443-1452, 2010.

26) Araki, M., et al.: Efficacy of the anti-IL-6 receptor antibody tocilizumab in neuromyelitis optica: a pilot study. Neurology. 82: 1302-1306, 2014.

27) Chihara, N., et al.: Plasmablasts as migratory IgGproducing cells in the pathogenesis of neuromyelitis optica. PLoS One. 8: e83036, 2013.

28) Qin, Y., et al.: Clonal expansion and somatic hypermutation of $\mathrm{V}(\mathrm{H})$ genes of $\mathrm{B}$ cells from cere- brospinal fluid in multiple sclerosis. J Clin Invest. 102: 1045-1050, 1998.

29) Owens, G.P., et al.: Restricted use of VH4 germline segments in an acute multiple sclerosis brain. Ann Neurol. 43: 236-243, 1998.

30) Baranzini, S.E., et al.: B cell repertoire diversity and clonal expansion in multiple sclerosis brain lesions. J Immunol. 163: 5133-5144, 1999.

31) Colombo, M., et al. Accumulation of clonally related B lymphocytes in the cerebrospinal fluid of multiple sclerosis patients. J Immunol. 164: 27822789, 2000.

32) Palanichamy, A., et al.: Immunoglobulin classswitched B cells form an active immune axis between CNS and periphery in multiple sclerosis. Sci Transl Med. 6: 248ra106, 2014.

33) Elliott, C., et al.: Functional identification of pathogenic autoantibody responses in patients with multiple sclerosis. Brain. 135: 1819-1833, 2012.

34) Serafini, B., et al.: Detection of ectopic B-cell follicles with germinal centers in the meninges of patients with secondary progressive multiple sclerosis. Brain Pathol. 14: 164-174, 2004.

35) Magliozzi, R., et al.: A Gradient of neuronal loss and meningeal inflammation in multiple sclerosis. Ann Neurol. 68: 477-493, 2010.

36) Kikuchi, Y., et al.: RP105-lacking B cells from lupus patients are responsible for the production of immunoglobulins and autoantibodies. Arthritis Rheum. 46: 3259-3265, 2002.

37) Jacobi, A.M., et al.: HLA-DRhigh/CD27high plasmablasts indicate active disease in patients with systemic lupus erythematosus. Ann Rheum Dis. 69: 305-308, 2010.

38) Kurtzke, J.F.: Rating neurologic impairment in multiple sclerosis: an expanded disability status scale (EDSS). Neurology. 33: 1444-1452, 1983.

39) Kinnunen, T., et al.: Specific peripheral B cell tolerance defects in patients with multiple sclerosis. $J$ Clin Invest. 123: 2737-2741, 2013.

40) Crotty, S.: $\mathrm{T}$ follicular helper cell differentiation, function, and roles in disease. Immunity. 41: 529$542,2014$.

41) Linterman, M.A., et al.: Foxp3+ follicular regulatory $\mathrm{T}$ cells control the germinal center response. Nat Med. 17: 975-982, 2011.

42) Matsushita, T., et al.: Reappraisal of brain MRI features in patients with multiple sclerosis and neuromyelitis optica according to anti-aquaporin-4 antibody status. J Neurol Sci. 291: 37-43, 2010. 
43) Lublin, F.D., Reingold, S.C.: Defining the clinical course of multiple sclerosis: results of an international survey. National Multiple Sclerosis Society (USA) Advisory Committee on Clinical Trials of New Agents in Multiple Sclerosis. Neurology. 46: 907-911, 1996.

44) Yednock, T.A., et al.: Prevention of experimental autoimmune encephalomyelitis by antibodies against alpha 4 beta 1 integrin. Nature. 356: 63-66, 1992.

45) Matloubian, M., et al.: Lymphocyte egress from thymus and peripheral lymphoid organs is dependent on S1P receptor 1. Nature. 427: 355-360, 2004.

46) Villar, L.M., et al.: Immunological markers of optimal response to natalizumab in multiple sclerosis. Arch Neurol. 69: 191-197, 2012.

47) Min, J.H., et al.: Development of extensive brain lesions following fingolimod (FTY720) treatment in a patient with neuromyelitis optica spectrum disorder. Mult Scler. 18: 113-115, 2012.

48) Nakamura, M., et al.: Differential effects of fingolimod on B-cell populations in multiple sclerosis. Mult Scler. 20: 1371-1380, 2014.

49) Nicoletti, F., et al.: Short-term treatment of relapsing remitting multiple sclerosis patients with interferon (IFN)-beta1B transiently increases the blood levels of interleukin (IL)-6, IL-10 and IFN-gamma without significantly modifying those of IL-1beta, IL-2, IL-4 and tumour necrosis factor-alpha. Cytokine. 12: 682-687, 2000.
50) Satoh, J., et al.: Microarray analysis identifies a set of CXCR3 and CCR2 ligand chemokines as early IFNbeta-responsive genes in peripheral blood lymphocytes in vitro: an implication for IFNbetarelated adverse effects in multiple sclerosis. $B M C$ Neurol. 6: 18, 2006.

51) Bellido, T., et al.: Transcriptional activation of the p21 (WAF1, CIP1, SDI1) gene by interleukin-6 type cytokines. A prerequisite for their prodifferentiating and anti-apoptotic effects on human osteoblastic cells. J Biol Chem. 273: 21137-21144, 1998.

52) Morse, L., et al.: Induction of cell cycle arrest and B cell terminal differentiation by CDK inhibitor p18 (INK4c) and IL-6. Immunity. 6: 47-56, 1997.

53) Dang, V.D., et al.: From the regulatory functions of B cells to the identification of cytokine-producing plasma cell subsets. Curr Opin Immunol. 28: 7783, 2014.

54) Matsumoto, M., et al.: Interleukin-10-producing plasmablasts exert regulatory function in autoimmune inflammation. Immunity. 41: 1040-1051, 2014.

55) Schneider, A., et al.: In active relapsing-remitting multiple sclerosis, effector $\mathrm{T}$ cell resistance to adaptive $\mathrm{T}$ (regs) involves IL-6-mediated signaling. Sci Transl Med. 5: 170ra115, 2013.

56) Trinschek, B., et al.: Kinetics of IL-6 production defines $\mathrm{T}$ effector cell responsiveness to regulatory T cells in multiple sclerosis. PLoS One. 8: e77634, 2013.

57) Hauser, S.L., et al.: B-cell depletion with rituximab in relapsing-remitting multiple sclerosis. $N$ Engl $J$ Med. 358: 676-688, 2008. 